\title{
Response of Microbial Consortia Culture Inoculation to Soil Moisture Status, Proline and Yield of Sorghum (Sorghum bicolar L.)
}

\author{
N. A. Kakde, G. R. Hanwate, P. H. Gourkhede \\ AICRP on Dry Land Agriculture, Vasantarao Naik Marathawada Krushi Vidyapeeth, Parbhani, Maharashtra, \\ India
}

\section{ABSTRACT}

Article Info

Volume 8, Issue 4

Page Number : 05-13

\section{Publication Issue}

July-August-2021

\section{Article History}

Accepted : 25 June 2021

Published : 02 July 2021
Plant secondary metabolites play vital role in plant stress response. In this study we investigated root colonization of sorghum (Sorghum bicolar) infected by two different types of microbial consortia culture (MC1 \& MC2) leads to alteration in the biosynthesis of secondary plant metabolites including phytoharmones and osmolyte proline under drought stress. The promising microbial consortia procured from authentic sources (Department of Microbiology CRIDA, Hyderabad and that consortia culture contain mixture of effective beneficial microbes such as $\mathrm{N}$-fixing bacteria, PGPR and mycorrhizal fungi). Application of microbial consortia culture through soil application and seed treatment to sorghum along with Recommended Dose Of Fertilizer (RDF) showed increased soil moisture content and chlorophyll pigments as compared to uninoculated controls as well as drought stressed plants. Proline content was increased in plants inoculated with microbial consortia under both normal as well as drought conditions. An obvious increase grain yield and dry matter yield through application of microbial consortia with soil application and seed treatments in normal and drought condition respectively.

Keywords : Microbial consortia, Drought, Soil moisture, Proline, Chlorophyll, Yield

\section{INTRODUCTION}

Drought is an abiotic stress resulting in devastation of agricultural crops and causing considerable losses in yield (de Vries et al., 2012). Drought stress is among the most destructive abiotic stresses that increased in intensity over the past decades affecting world's food security. Drought stress may range from moderate and short to extremely severe and prolonged duration, restricting the crop yields (Austin, 1989; Pereira and Chavess, 1995; Bottner et al., 1995). Plant are constantly exposed to a wide range of environmental stresses which limit plant productivity. Over several centuries, breeding programmes have focused on generating crop species with enhanced productivity under suboptimal environmental conditions. Much work has been carried out in understanding the mechanisms behind plant 
responses to various biotic and abiotic stresses (Staskawicz et al. 1995; Quartacci et al. 2000; Sgherri et al; 2000). Drought affect plant-water potential and turgor, enough to interfere with normal functions (Hsiao 2000) changing physiological and morphological traits in plants (Rahdari and Hoseini, 2012). Groth reduction under drought stress has been studied in several crops such as barley (Samarh, 2005), maize (Kamara et al., 2003), rice (Lafitte et al., 2007) and wheat (Rampino et al., 2006). Fresh weight and water content are common growth parameter that are affected by drought (Jaleel et al., 2009). Drought also induced free radical affecting antioxidant defences and Reactive Oxygen Species (ROS) such as superoxide radicals, hydrogen peroxide and hydroxyl radical resulting in oxidative stress. At high concentration ROS can cause damage to various levels of organization (Smirnoff, 1993), like initial lipid peroxidation, membrane deterioration and degrade proteins, lipids and nucleic acids in plants (Hendry, 2005; Sgherri et al., 2000; Nair et al., 2008). Nevertheless, under drought stress the decrease in chlorophyll content was symptom of photooxidation (Anjum et al., 2011; Rahdari et al., 2012). Millions of microbes inhabit plant root system forming a complex ecological community that influences plant growth and productivity through its metabolic activities and plant interactions (Berg 2009). The role of microorganisms in plant growth, nutrient management and biocontrol activity is very well established. These beneficial microorganisms colonize the rhizosphere/endo-rhizosphere of plants and promote growth of the plants through various direct and indirect mechanisms (Grover et al., 2011). Furthermore, the role of microorganisms in management of biotic and abiotic stresses is gaining importance.

In a country like India where large population depend on agriculture for their livelihoods, growth of agriculture assumes greater importance. The agriculture in India mainly relies on two monsoon rains namely South West Monsoon and North East Monsoon. The recent failure in mansoon rain leaves $45 \%$ of the cropping area under drought (Indian Meteorological Department 2009). Thus, the identification of beneficial microorganisms which mediate drought resistance in crop plants assumes greater importance. Since three years there is continuous drought in Maharastra. Due to moisture stress there is significantly decreased in yield.

Microorganisms can help the crop to withstand in drought condition, by providing to the favorable environment to the crops. Thus keeping in view present study was conducted. There is necessity to use microbial inoculants formulations as an integral part of sustainable agricultural practices. These can be achieved by increasing and extending the role of microbial inoculation. Later, which help in minimizing the adverse environmental effect. (Vijaykumar Gagaraddi and GP Bramaprakash 2018). In the current study, the microbial consortia were tested to enhance drought resistance in sorghum (Sorghum bicolar L.) is an important cereal crop in India. Sorghum rank fifth among world cereals after wheat, rice, maize and barely (Sato et al., 2004 and Khalil, 2008). The crop is primarily grown in the warm dry climates of India, to used as food and fodder (Alagarswamy and Chandra, 1998). In India area under sorghum is $11.7 \mathrm{~m}$ ha- 1 with production $10.5 \mathrm{mt}$. In india, the share of sorghum out of total cropped area is about 7\% and it contributes about $6.2 \%$ of total food grain production. Sorghum production in the country is largely concentrated in Maharashtra, Karnataka, Madhya Pradesh, Andrapradesh, Rajasthan, Tamil Nudu, Uttar Pradesh and Gujarat.

\section{MATERIALS AND METHODS}

The present experiment (2019) was laid out at VNMKV. Parbhani Center of All India Coordinated Research Project on Dry land Agriculture in a randomized block design, with seven treatments and 
three replications under sorghum (Sorghum bicolar L.) with the objective to evaluate the performance of microbial consortia for drought tolerance and to assess their effect on soil moisture, proline, chlorophyll and yield under water stress condition. The application of microbial consortia were done at the time of sowing by seed treatment @ $100 \mathrm{~g}$ consortia powder per $10 \mathrm{~kg}$ of seed and by soil application @ $2.5 \mathrm{~kg}$ consortia culture powder ha-1 through $50 \mathrm{~kg}$ FYM/ vermicompost. The treatments are T1: Seed treatment with consortia culture-1 (MC1), T2: Soil application of consortia culture-1 (MC1), T3: Seed treatment + soil application of consortia culture-1 (MC1), T4: Seed treatment with consortia culture-2 (MC2), T5: Soil application of consortia culture-2 (MC2), T6: Seed treatment + soil application of consortia culture-2 (MC2), T7: Absolute control.

\section{Determination of chlorophyll from leaves of sorghum}

Chlorophyll content was measured by SPAD meter (mg g-1) at critical growth stages of sorghum.

\section{Determination of proline}

Proline content was determined as described by Bates et al. (1973). Briefly, Leaf tissue $(0.5 \mathrm{~g})$ for fresh plant leaf and $(0.2 \mathrm{~g})$ for dry plant leaf was homogenized in $5 \mathrm{Ml}$ of sulphosalicylic acid (3\%) and centrifuged at $10,000 \mathrm{~g}$ for $30 \mathrm{~min}$. About $3 \mathrm{ml}$ of the supernatant was taken in a test tube to which $2 \mathrm{ml}$ ninhydrinreagent were added. The reaction mixture was boiled in a water bath at $100{ }^{\circ} \mathrm{C}$ for $30 \mathrm{~min}$. After cooling the reaction mixture, four $\mathrm{ml}$ of toluene was added, and the sample was vortexed for $30 \mathrm{~s}$; the upper phase containing proline was measured with a spectrophotometer at $520 \mathrm{~nm}$ using toluene as a blank. Proline content was expressed in $\mu \mathrm{mol} / \mathrm{g}$ FW by using L-proline as a standard.

\section{Determination of soil moisture}

Soil moisture content (\%) was estimated by gravimetric method by placing about $10 \mathrm{~g}$ soil sample in oven at $105^{\circ} \mathrm{C}$, and dry for 24 hours.

\section{Determination of grain and dry matter yield of sorghum}

Grain yield (Kg ha-1) was recorded from each net plot and converted on hectare basis. For dry matter yield the plant were uprooted for dry matter study, excluding root system and were air dried under sun light for eight days and subsequently dried in the thermostatic oven at $64^{\circ} \mathrm{C}$ till they were completely dried. The final constant dry weight was recorded as total dry matter accumulation per plant and per hectare yield was calculated.

\section{RESULT AND DISCUSSION}

Effect of microbial consortia inoculation on chlorophyll content in sorghum Chlorophyll content in sorghum, indicated significant effect of microbial consortia in flag leaf and dough stage of sorghum crop. The chlorophyll content ranged from $4.90-7.06 \mathrm{mg}$ $\mathrm{g}-1$ at flag leaf stage and $4.80-6.20 \mathrm{mg} \mathrm{g}-1$ at dough stage in sorghum crop. The significantly highest chlorophyll content $7.06 \mathrm{mg}$ g- 1 was noticed at flag leaf stage and $6.20 \mathrm{mg} \mathrm{g-1}$ at dough stage of sorghum crop with application of microbial consortia cultureC2 through seed treatment + soil application (T6). The treatment T3 (seed treatment + soil application of consortia culture- C1) was found to be at par with T6 found $6.40 \mathrm{mg} \mathrm{g}-1$ and $6.20 \mathrm{mg}$ g-1 chlorophyll content at flag leaf and dough stage respectively. An extreme drought event with high temperature which lead to dramatic reduction in primary productivity (Ciais et al., 2005) which resulted in reduced plant development and leaf wilting. Consortia inoculation increased osmoregulant and showed the ability to grow under low moisture condition (Mapell et al., 2012). Hence the chlorophyll content with addition 
of microbial consortia through seed and soil facultative Methylotroph (PPPFM) @ 1: 100 dilution application recorded highest chlorophyll content in for $18 \mathrm{~h}$ have recorded higher germination, seedling leaf. Similar finding also reported by Raja and vigor and chlorophyll content.

Anandham, (2020) in the or pink pigmented

Table 1. Effect of microbial consortia inoculation on chlorophyll content in sorghum

\begin{tabular}{|c|c|c|}
\hline \multirow{2}{*}{ Treatments } & \multicolumn{2}{|c|}{ Total Chlorophyll (mg g $\left.{ }^{-1}\right)$} \\
\hline & Flag leaf & Dough Stage \\
\hline $\mathrm{T}_{1}$ : Seed treatment of consortia $\left(\mathrm{C}_{1}\right)$ & 5.16 & 5.16 \\
\hline $\mathrm{T}_{2}$ : Soil application consortia $\left(\mathrm{C}_{1}\right)$ & 5.46 & 5.36 \\
\hline $\begin{array}{l}\text { T3: Seed treatment }+ \text { Soil application of } \\
\text { consortia }\left(C_{1}\right)\end{array}$ & 6.40 & 6.20 \\
\hline $\mathrm{T}_{4}$ : Seed treatment of consortia $\left(\mathrm{C}_{2}\right)$ & 5.63 & 5.33 \\
\hline $\mathrm{T}_{5}$ : Soil application of consortia $\left(\mathrm{C}_{2}\right)$ & 5.60 & 5.26 \\
\hline $\begin{array}{l}\mathrm{T}_{6}: \text { Seed treatment }+ \text { Soil application of } \\
\text { consortia }\left(\mathrm{C}_{2}\right)\end{array}$ & 7.06 & 6.20 \\
\hline $\mathrm{T}_{7}:$ Absolute control & 4.90 & 4.80 \\
\hline S.Em. \pm & 0.42 & 0.29 \\
\hline C.D.at $5 \%$ & 1.32 & 0.92 \\
\hline C. V. \% & 12.81 & 9.40 \\
\hline
\end{tabular}

Effect of microbial consortia inoculation on proline content in leaves under drought condition

There was significant changes in proline content of plant leave due to use of microbial consortia. The proline content in leaves during dry spell ranged between 0.31-0.86 $\mu \mathrm{g}$ g- 1 and at harvesting stage is $0.74-1.29 \mu \mathrm{g}$ g- . The significant and highest proline content $0.86 \mu \mathrm{g}$ - 1 was noticed with the application of microbial consortia culture-C2, through seed treatment + soil application (T6) during dry spell. Similarly the proline content in leaves was maximum $1.29 \mu \mathrm{g}$ g-1 at harvesting stage with use of microbial consortia culture-C2 through, seed treatment + soil application in T6 in sorghum. The treatment T3 showed the at par result to the treatment T6. Accumulation of some compatible solute in plant during drought or salinity could make the relative cellular osmatic potential to retain the water absorption ability.

Proline is one of the compatible solute like those. The increased in proline content could induced the production against the osmotic stress generated by drought or salinity (Liu and Zhu, 1997). Similar results were reported by Kalindeee and Borkar (2013) in sorghum seed bacterization with four rhizobacterial isolate viz., Serratia marcescens L1SC8, Pseudomonas putida L3SC1, Enterobacter cloacae L1CcC1 and Serratia marcescens. L2FmA4 were found beneficial to mitigate drought stress effect in sorghum. This was attributed to increase in osmolytes i.e. proline accumulation. 
Table 2. Effect of microbial consortia inoculation on proline content in leaves under drought condition

\begin{tabular}{|l|c|c|}
\hline \multicolumn{1}{|c|}{ Treatment } & \multicolumn{2}{c|}{ Proline content $\left(\mathbf{u g ~ g}^{-\mathbf{1}}\right)$} \\
\cline { 2 - 3 } & Dry spell & Harvest \\
\hline $\mathrm{T}_{1}:$ Seed treatment of consortia $\left(\mathrm{C}_{1}\right)$ & 0.76 & 0.84 \\
\hline $\mathrm{T}_{2}:$ Soil application consortia $\left(\mathrm{C}_{1}\right)$ & 0.69 & 1.03 \\
\hline $\mathrm{T}_{3}:$ Seed treatment + Soil application of consortia $\left(\mathrm{C}_{1}\right)$ & 0.85 & 1.10 \\
\hline $\mathrm{T}_{4}:$ Seed treatment of consortia $\left(\mathrm{C}_{2}\right)$ & 0.79 & 0.96 \\
\hline $\mathrm{T}_{5}:$ Soil application of consortia $\left(\mathrm{C}_{2}\right)$ & 0.80 & 0.93 \\
\hline $\mathrm{T}_{6}:$ Seed treatment + Soil application of consortia $\left(\mathrm{C}_{2}\right)$ & 0.86 & 1.29 \\
\hline $\mathrm{T}_{7}:$ Absolute control & 0.31 & 0.74 \\
\hline S.Em. \pm & 0.05 & 0.06 \\
\hline C.D.at 5\% & 0.17 & 0.18 \\
\hline C. V. $\%$ & 12.79 & 10.56 \\
\hline
\end{tabular}

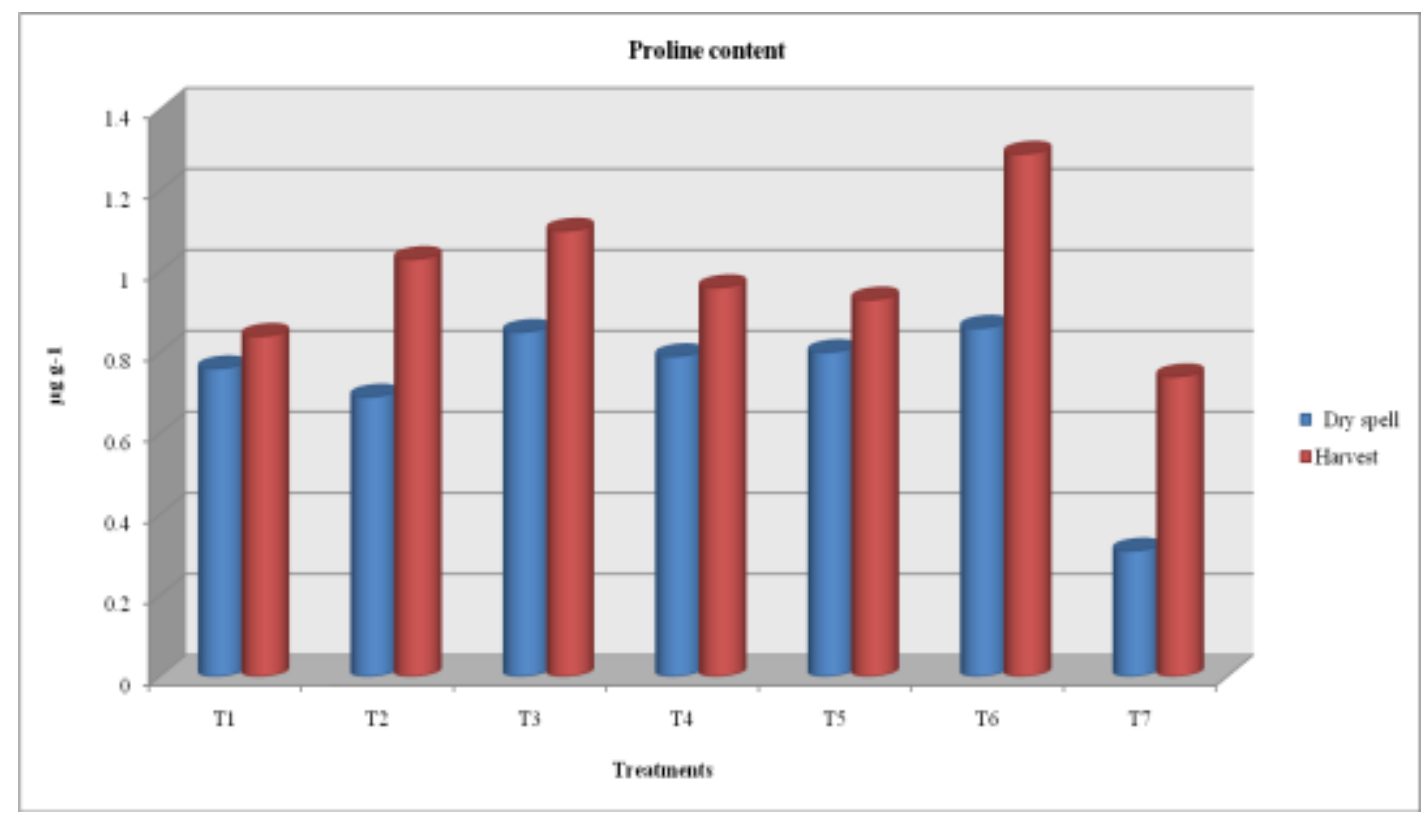

Fig 4.1 Effect of microbial consortia on proline content during dry spell and harvesting stage of sorghum.

\section{Effect of microbial consortia inoculation on soil moisture content in sorghum}

The data showed that the application of microbial consortia (C1 and C2) through seed treatment and soil application and both in conjunction has significant effect on moisture content of soil in various growth stages of sorghum. The moisture percentage during dry spell ranged from 21.19 to 24.45 percent. The highest percent moisture (24.45\%) was recorded in treatment T6 during dry spell was noted in treatment T7 of absolute control. The moisture content at flowering stage is in ranged from 25.43-29.98 \%. The maximum moisture content $(29.98 \%)$ was noticed in the treatment T6 (seed treatment + soil application of microbial consortia culture-C2). The treatment T3 (seed treatment + soil application of consortia culture- C1 along with $\mathrm{RDF}$ )which was at par to the treatment T6. Moisture content at harvest stage of sorghum ranged from 15.43 to 19.61 percent. The highest moisture content at harvest stage was recorded with application of microbial 
consortia through seed treatment + soil application of consortia culture- C2. Followed by treatment T2 (soil application of consortia culture- C2) recorded the moisture content $18.57 \%$. It was observed that Plant Growth Promoting Rhizobacteria (PGPR) could play a significant role in alleviation of drought stress in plants. These beneficial microorganisms colonize the rhizosphere/endo-rhizosphere of plants and impart drought tolerance by conserving soil moisture in soil and by producing exopolysaccharides (ESP), phytohormones, 1aminocyclopropane-1-carboxylate (ACC) deaminase, volatile compounds, inducing accumulation of osmolytes etc. in acquisition of drought tolerance (Sai Shiva Krishna et al., 2015).

Table 3. Effect of microbial consortia inoculation on soil moisture content in sorghum

\begin{tabular}{|c|c|c|c|}
\hline \multirow[b]{2}{*}{ Treatment } & \multicolumn{3}{|c|}{ Moisture content (\%) } \\
\hline & $\begin{array}{c}\text { Dry } \\
\text { spell }\end{array}$ & Flowering & Harvesting \\
\hline $\mathrm{T}_{1}$ : Seed treatment of consortia $\left(\mathrm{C}_{1}\right)$ & 23.72 & 26.99 & 17.09 \\
\hline $\mathrm{T}_{2}:$ Soil application consortia $\left(\mathrm{C}_{1}\right)$ & 23.14 & 25.77 & 18.57 \\
\hline $\begin{array}{l}\mathrm{T}_{3}: \text { Seed treatment }+ \text { Soil application of } \\
\text { consortia }\left(C_{1}\right)\end{array}$ & 24.32 & 27.81 & 18.28 \\
\hline $\mathrm{T}_{4}:$ Seed treatment of consortia $\left(\mathrm{C}_{2}\right)$ & 22.07 & 29.18 & 17.61 \\
\hline $\mathrm{T}_{5}:$ Soil application of consortia $\left(\mathrm{C}_{2}\right)$ & 25.00 & 26.32 & 15.41 \\
\hline $\begin{array}{l}\mathrm{T}_{6}: \text { Seed treatment }+ \text { Soil application of } \\
\text { consortia }\left(\mathrm{C}_{2}\right)\end{array}$ & 24.45 & 29.98 & 19.61 \\
\hline $\mathrm{T}_{7}:$ Absolute control & 21.19 & 25.43 & 15.43 \\
\hline S.Em. \pm & 0.67 & 0.79 & 0.71 \\
\hline C.D.at $5 \%$ & 2.09 & 2.46 & 2.23 \\
\hline C. V. \% & 7.96 & 7.00 & 8.14 \\
\hline
\end{tabular}

\section{Effect of microbial consortia on yield and dry matter yield of sorghum under water stress condition}

The significant and highest $2027 \mathrm{~kg}$ ha-1 grain yield of sorghum recorded with application of treatment T6 (seed treatment + soil application of consortia culture- C2). Treatment T3 and T2 was found at par with T6. Treatment T3 (seed treatment + soil application of consortia culture- C1) recorded $2004 \mathrm{~kg}$ ha-1 grain yield. Similarly dry matter yield was significantly affected with the administration of different treatments of microbial consortia culture C1 and C2. The values of dry matter ranged between 4310 to $4966 \mathrm{~kg}$ ha-1, sowing significant and maximum dry matter yield $4966 \mathrm{~kg}$ ha-1 with administration of treatment $\mathrm{T} 6$, which contain seed treatment in conjunction with soil application of consortia culture C2. Treatment T6 produced 15 percent more yield over control. Treatment T3 was found at par with treatment T6 and consortia culture- C2 was found more effective to producing grain and straw yield of sorghum under dry spell of 16 days. Therefore production of proline, sugar and osmoregulant content in plant leaf and root (Shelvakumar et al. 2012) The production of proline and osmoregulants capable to withstand the water stress due to dry spell. These isolates were capable to increasing shoot and leaf biomass, shoot length and photosynthesis. (Kavya et al. 2015) Activities of drought challenged plant. Thus these bacteria contribute to improved plant adaption to drought through a water stress induced promotion ability and resulting in grain yield and straw yield of sorghum. 
The higher concentration of consortia culture contributing to the formation of hydrophilic biofilm around the roots acting as an additional strength to protect the root system from soil hardness (Rossi et al. 2012; Xu et al. 2013).

Table 4. Effect of microbial consortia on yield and dry matter yield of sorghum under water stress condition

\begin{tabular}{|l|c|c|}
\hline \multicolumn{1}{|c|}{ Treatment } & $\begin{array}{c}\text { Seed yield } \\
\left(\mathbf{k g ~ h a}^{-\mathbf{1}}\right)\end{array}$ & $\begin{array}{c}\text { Dry matter yield } \\
\left(\mathbf{k g ~ h a}^{-\mathbf{1}}\right)\end{array}$ \\
\hline $\mathrm{T}_{1}:$ Seed treatment of consortia $\left(\mathrm{C}_{1}\right)$ & 1733 & 4792 \\
\hline $\mathrm{T}_{2}:$ Soil application consortia $\left(\mathrm{C}_{1}\right)$ & 1890 & 4612 \\
\hline $\begin{array}{l}\mathrm{T}_{3}: \text { Seed treatment + Soil application of } \\
\text { consortia }\left(\mathrm{C}_{1}\right)\end{array}$ & 2004 & 4869 \\
\hline $\mathrm{T}_{4}:$ Seed treatment of consortia $\left(\mathrm{C}_{2}\right)$ & 1756 & 4598 \\
\hline $\mathrm{T}_{5}:$ Soil application of consortia $\left(\mathrm{C}_{2}\right)$ & 1753 & 4499 \\
\hline $\begin{array}{l}\mathrm{T}_{6}: \text { Seed treatment }+ \text { Soil application of } \\
\text { consortia }\left(\mathrm{C}_{2}\right)\end{array}$ & 2027 & 4966 \\
\hline $\mathrm{T}_{7}:$ Absolute control & 1720 & 4310 \\
\hline S.Em. \pm & 66.26 & 100.59 \\
\hline C.D.at $5 \%$ & 206.43 & 313.39 \\
\hline C. V. $\%$ & 9.23 & 8.73 \\
\hline
\end{tabular}

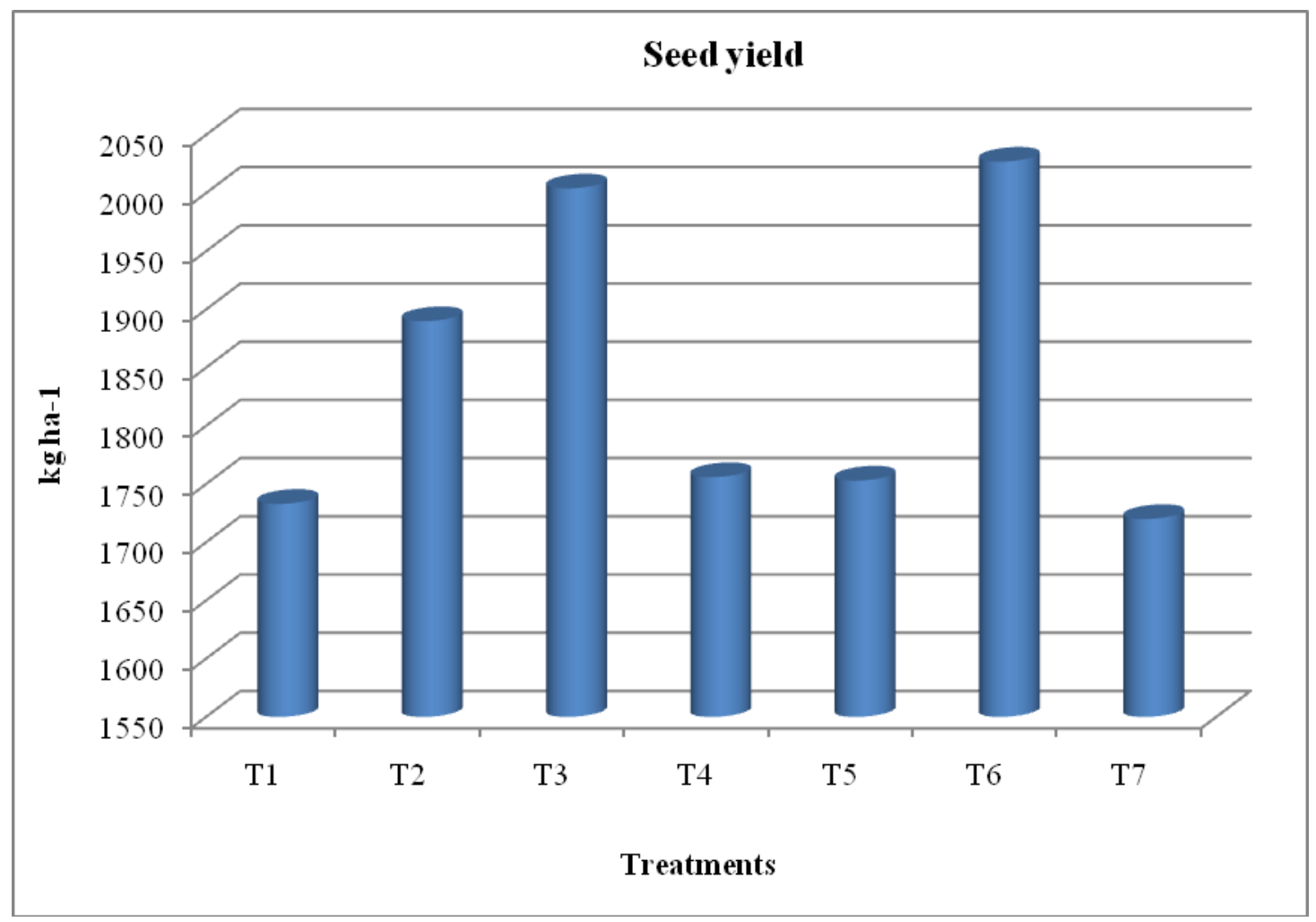




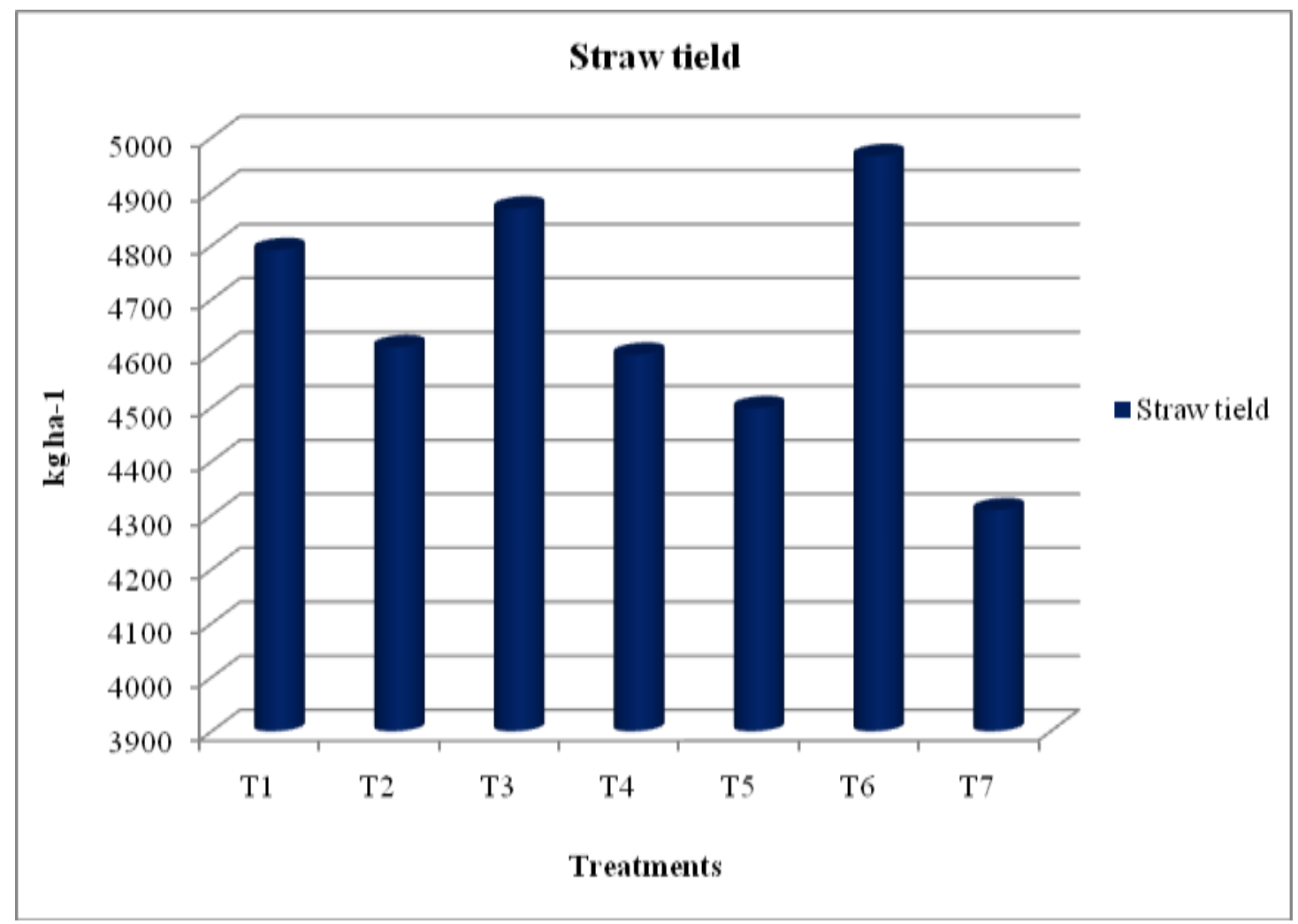

\section{REFERENCES}

[1]. Alagarswamy G, and Chandra S, 1997. Pattern analysis of international sorghum multienvironment trials for grain-yield adaptation. Theor Appl Genet, 96: 397-405

[2]. Anjum, S., Xie, X., Wang, L., Saleem, M., Man, C., Lei, W., 2011. Morphological, phyological and biochemical response of plants to drought stress. J., Afr. Agric. Res. 6, 2026-2032

[3]. Austin R. B. 1989 Prospect for improving crop production in stressful environment. In: Hamyln. G. J., Flowers T. J., Jones M. B., (Eds), Plants Under Stress Biochemistry, physiology and Ecology and Their Application to Plant Improvement. Cambridge University Press, Cambridge, pp. 235- 248.

[4]. Berg, G., 2009. Plant microbe interactions promoting plant growth and health: perspectives for control use of microorganisms in agriculture, Appl. Microbiol. Biotechnol. 84, 11-18

[5]. Bottner, P., Couteaux, M. M., Vallejo, V. R., 1995. Soil organic matter in Mediterraneantype ecosystems and global climate changes: a case study-the soils of the Mediterranean basin. In: Jose, M,. Oechel, W. C. (Eds.), Global Change and Mediterranean-type Ecosystems. Ecological studies, 117. Springer-Verlag, New York, pp, 306-325

[6]. Ciais, P., Reichstein, M., Viovy, N., Grainier, A., Ogee, J., Allard, V., 2005. Europe- wide reduction in primary productivity caused by the heat and drought in 2003. Nature 437; 529533

[7]. De Vries F T, Liiri M E, Bjornlund L, Setala H M, Christensen S, Bardgett R D. 2012. Legacy effect of drought on plant growth and the soil web. Oecologia, 170, 821-833 
[8]. Grover, M., Ali SkZ, Sandhya, V., Venkateswaralu, B., 2011. Role of microorganisms in adaptation of agricultural crops to abiotic stresses. World J. Microbiol, Biotechnol. 27, 1231-1240

[9]. Hendry, G. A., 2005. Oxygen free radical process and seed longevity. Seed Sci. J. 3, 141147.

[10]. Hsiao, A, 2000. Effect of water deficit on morphological and physiological characterizes in Rice (Oryza sativa). J. Agric, 3, 93-97.

[11]. Indian Meteorological Department 2009. Present status of drought. Drought Bull 1:3- 26

[12]. Jaleel, C. A., Manivannan, P., Wahid, A., Frooq, M., AI-Juburi, H. J., Somasundaram, R., Vam, R. P., 2009. Drought stress in plant: a review on morphological characteristic and pigments composition. Int. J. Agric. Biol. 11, 100-105

[13]. Kalindee S Shinde and SG Borkar (2018) Seed bacterialization induced proline content in sorghum bicolor crop under severe drought condition. International Journal of Chemical Studies 6(2): 1191-1194

[14]. Kamara, A, Y,. Menkir, A., Badu-Apraku, B., Ibikunle, O., 2003. The influence of drought stress on growth, yield, and yield components of selected maize genotypes. J. Agric. Sci. 141, 43-50

[15]. Kavya Y., Trimurthulu N., Vijaya Gopal A., Madhu Vani and Prasad N.V. 2020. Effect of inoculation of microbial consortia on soil physicochemical and nutrient status. British Journal of Applied Science and Technology. 39(4): $1-8$

[16]. Lafitte, H, R., Yongsheng, G., Yan, S., Lil, Z. K., 2007. Whole plant responses, key process, and adaptation to drought stress: the case of rice. J. Exp. Bot. 58, 169-175

[17]. Llu J., and Zhu J. K. 1997. Proline accumulation and salt stress induced gene expressing in a salt by presentative nutrient of Arabiodopsis. Plant physiology. 114: 591-596
[18]. Mapelli, F., Marsco, R., Balloi, A., Rolli E., Cappitelli, F., Daffonchio, D., and Borin,

[19]. S. 2012. Mineral-microbes interactions: biotechnological potential of bioweathering. J. Biotechnol 157: 473-481

[20]. Nair, A., Abraham, T. K., Jaya, D.S., 2008. Studies on the changes in lipid peroxidation and antioxidants in drought stress induced Cowpea (Vigna unguiculata L.) varieties. J. Environ. Biol. 29, 689-691

[21]. Pereira, J, S., Chaves, M. M., 1995 Plant responses to drought under climate change in Mediterranean-type ecosystems. In: Jose, M., Oechel, W, C, (Eds.), Global change and Mediterranean-type Ecosystems. Ecological studies, 117, Springer-Verlag, New York, pp, 140-160

[22]. Quartacci MF, Pinzino C, Sgherri CLM, Dalla Vecchia F, Navari-Izzo F 2000. Growth in excess copper induced changes in the lipid composition and fluidity of PSII-enriched membranes in wheat. Physiol Plant 108: 87- 93

[23]. Rahdari, P., Hoseini, S,M., Tavakoli, S., 2012. The studying effect of drought stress on germination, proline, sugar, lipid, protein and chlorophyll content in Purstane (Portulaca oleraceae L.) leaves. J. Med. Plants Res. 6, 15391547

[24]. Rahdari, P., Hoseini, S. M., 2012. Drought stress, a review. Int. J. Agron. Plant Prod. 3, 443-446

[25]. Raja K., and Anandham R. 2020. Influsing microbial consortia on seed quality and seedling vigour in pearlmillet (Pennisetum glaucum L.) Microbiology Research Journal International. 30(4): 43-55

[26]. Rampino, I., Pataleo, S., Gerardi, C., Perotta, C., 2006. Drought stress responses on wheat: physiological and molecular analysis of resistant and sensitive genotype. Plant Cell Environ, 29, 2143-2152. 
[27]. Rossi, F., Potrafka, R.M., Pichel, F.G., and De Philipps, R. 2012. The role of the exopolysaccharides in enhancing hydraulic conductivity of biological soil crusts. Soil Biol Biochem 46: 33-40

[28]. Sai Shiva Kumar Prasad Vurukonda, Sandhya Vardharajula, Manjari Shrivastava, Ali SkZ 2015. Enhancement of drought stress tolerance in crops by crops by plant growth promoting rhizobacteria. Microbiological Research 2(27): 13-24

[29]. Samarah, N. H., 2005. Effect of drought stress on growth and yield of barley. Agron.

[30]. Sustain. Dev, 25, 145-149

[31]. Sato S, Clemente T, Dweikat I, 2003. Identification of an elite sorghum genotype with high in-vitro performance capacity. In Vitro Cell. Dev. Biol-Plant, 40:57-60.

[32]. Sgherri CLM, Maffei M, Navari-Izzo F 2000. Antioxidative enzymes in wheat subjected to increasing water deficit and rewatering. J Plant Physiol 157: 273-279

[33]. Shelvakumar G., Reeta S., and Thamizhiniyan P., 2012. Response of biofertilizers on growth, yield attributes and associated protein profiling change of black gram (Vigna mungo L.) World Applied Sci. J. 16(10): 1368-1374

[34]. Smirnoff, N., 1993. The role of Reactive Oxygen in the response of Plants to water deficit and desiccation. J. New Phytol. 125: 27-30

[35]. Staskawicz BJ, Ausubel FM, Baker BJ, Ellis JG, Jones JD 1995. Molecular genetics of plant disease resistance. Science 268: 661-667

[36]. Vijaykumar Gangaradi and GP Brahmaprakash 2018. Evaluation of selected microbial consortium formulations on growth of green gram (Vigna radiate L.) International Journal of Chemical Studies. 6(6): 1909-1913

[37]. Xu T.H., Rossi, F. Colica, G., Deng, S.Q., De philipps, R., and Chen, L.Z., 2013. Use of cyanobacterial polysaccharides to promote shrub performance in deseart soils: a potential approach for the restoration of desertification .

\section{Cite this article as :}

Sh 